\title{
HUMAN ASPECTS ON THE RE-ORGANIZATION AND RE- ALLOCATION OF RESOURCES ON FAMILY FARMS
}

\author{
N. Westermarck \\ Department of Agricultural Economics, Helsinki University
}

Received December 2, 1963

In order that agriculture should obtain its share in the economic progress of society in the same ratio as other industries, its labour productivity should rise in the same ratio. This, however, is not usually possible on family farms unless the farm business is expanded either horizontally, by adding land area, or vertically, by raising the degree of intensity. Consequently, ceteris paribus, the managing of a larger farm business requires far more competence from the farmer, since merely the maintaining of competitive ability in a progressive society calls for increasing requirements without further re-organization and re-allocation of resources. Production methods also rapidly change as a result of research and experiments so that the demands on the ability of the farmer are continuously growing.

Psychology presents many definitions of intelligence. However, it is interesting to note in this connection, that the definition of the German William STERN is universally accepted, according to which intelligence indicates the general capacity of man to adapt himself expediently to $\mathrm{n} \mathrm{e} \mathrm{w} \mathrm{sit} u$ a t i o $\mathrm{n} \mathrm{s}$ in life. This signifies that it can be presumed à priori that there is a positive correlation between ability and production alterations.

The significance of the human factor, where allocation and reorganization of resources are concerned, can be expressed in the following hypothesis.

Competent farmers with professional training are more likely to carry out alterations for promoting the profitableness of their farm than less competent farmers with no professional training. In this they are forced to take considerable risks and to make themselves more dependent on the granting of credit and the capital market.

As the risks attached to alterations are, ceteris paribus, greater for farmers of lesser ability, they are not as willing to make alterations. Their chances of failure are greater and consequently the adoption of new methods is not even motivated to the extent that it is for more able farmers. 
In the following, reference will be made to some empirical research work in which this problem has been touched upon, although the research in question has not concentrated solely on this problem.

In order to elucidate the human factors behind the acceptance of new practices some remarks of the Dutch rural sociologist van DEN BAN (1) may be quoted. "On numerous farms in the Netherlands, it would be possible to increase the income by intensified production in various agricultural branches, such as poultry, pigs, horticulture and others. Such an intensification calls, of course, for a lot of capital, which the farmers often do not have but which they could borrow if they liked to. Often, however, they do not want to do so. Why not? Quite probably the reason is at least partly to be found in the experiences of subsistence farming of former centuries, which still constitute a part of many farmers' mental make-up, and continue to influence their entire way of thinking. In a preponderantly subsistence economy the farmer clearly could not invest money except for buying more land in order to increase his income. If he does not sell his farm products, investments will not increase the profit of his enterprise, but only the level of household consumption or the amount of leisure. This practice was adopted usually also in respect to those few commodities which could ever then be bought from specialized farms.

This obviously represented a theoretical loss, since home production often required comparatively more labour, but such a consideration was not important in an economy of this type, because no alternative way to use the family manpower existed.

Significant elements of this pattern persist in many communities to the present day, long after the Dutch farmers have ceased to operate in a subsistence economy and have begun to produce for a world market. In the same way, high value is attached to the economic autarchy of the farm, which might impede transition to more specialized farming and intensive capital investment with the aid of loans. And last but not least farming as a way of life is regarded as being based on actual manual labour rather than on the application of managerial skills."

Obviously ideas of this kind tend to retard the adjustment of the farm to changing circumstances; when a farmer is given to this traditional way of thinking, it is more difficult for him to accept new practices than it is for a person who views his farm largely as a modern business enterprise. However, agricultural advisors quite often except all farmers to think and act as business managers and advocate new practices, which are profitable when the farmers in fact calculate their profits in a businesslike way, but not when they use the traditional economic arguments ideas.

As is well known, the production organization on individual farms and in different regions depends largely on the law of comparative advan$\mathrm{t}$ a g e. However, it can frequently be observed in practice that certain measures of specialization have been executed without natural and economic conditions in any way seeming to furnish an explanation for such a phenomenon. As examples of livestock husbandry it may be stated that a very limited area in Finland, i.e. the Swedish speaking district of Ostro-Bothnia, which holds only about $4 \%$ of the total agricultural population of the country, represents nearly one half of the 
total farm fur production in Finland. Occasionally one comes across with counties in which poultry farming is many times that of the neighbouring counties, without the economic conditions differing from each other in any way.

Even in crop husbandry similar specialization can be observed, in circumstances which do not depend, at least not primarily, on the natural and economic conditions being especially favourable for the branch of production in question. For example, one single parish in the aforementioned Swedish speaking Ostro-Bothnia produces $40 \%$ of the tomato crop of Finland. The location of this area is fairly remote from any important market centres. Patches of cultivated strawberry growing are also to be found without any special economic and natural reasons accounting for the choice of locality.

In these examples the human factor is obviously the most important promoter of the re-organization. Natural and economic circumstances have probably not especially favoured these branches of production, but the phenomena may be explained by the fact that the farmers have been in need of an extra income. Some enterprising person has taken the initiative, succeeded, and others have followed his example. This is a healthy phenomenon, because regional specialization in some branch of production makes it possible to utilize many advantages of large scale production. This applies to the rationalization of the primary production as well as to the marketing of the products.

As Partenheimer and Bell (5) in USA have emphasized, the new technology is one of the most dynamic forces affecting decisions today. "All farmers must face the choice of using a proved production technique which appears to be most profitable, a more flexible, proved technique or production which allows him to shift to another method with smaller losses through obsolescence or a promising but unproved production technique. The choice depends on the farmer's expectations concerning the technological innovations in agriculture, his marginal utility for gains or marginal disutility for losses, his goals or ends, and many other personal and/or subjective factors."

The possibilities for most farmers to follow technical developments in different fields are limited. On the other hand, the ever toughening competition induces an adoption of the achievements of technique and research at an ever growing pace. The human capacity is not, however, a sufficient basis for becoming a specialist in a large sector. To enable a many-sided agriculture to apply the best possible forms of technique, different specialists should be employed in the same undertaking. However, this is not usually possible on family farms.

Emphasis has been laid on the fact that modern planning methods based on linear planning provide a greater margin of security to re-organization because the determining of the various alternatives lies on a more exact basis. This is true, but it should be added that the farmer's final choice from among the alternatives is governed by his interest in the different alternatives as well as by his estimates as to how he will be able to realize these in practice.

In this connection one might refer to the statement of the English researcher, Daw (3): "Nowadays farming is a highly complex business demanding considerable 
ability. With new developments and technical problems it becomes increasingly difficult for one man to keep abreast of all the sections of a mixed farm. By concentrating on no more than four lines of production, a farmer's managerial ability is not dispersed over too wide a field and he can more easily become expert in a limited number of enterprises. Only the exceptionally gifted farmer can hope to attain the high levels of managerial proficiency in more than four or five enterprises.»

The question of the adoption of new methods has been dealt upon by several researchers. The matter is touched upon in the following only in regard to those parts where the characteristics of the adopter categories are dealt with, and not the diffusion process itself. RoGERs (7), in Ohio, USA, observed in his studies that the influence of age in the adoption of innovations is not clear but that there is a tendency for older farmers to be less keen on innovations owing to their greater conservatism. Thus the average age of the innovator and the early adopter group was 38 years, while that of the laggards was 55 years. The difference was significant at the one percent level.

Another measure of specialization was used in Rogers's study. This index of specialization was computed as the ratio of PMWU's ${ }^{1}$ ) in a major farm enterprise to the total number of PMWU's in the farm operation times 100. Thus, a farmer with 300 PMWU's in his milch cattle enterprise and 500 in his total farm operation would have a specialization ratio of 60 . This indicates that 60 percent of his farms labour requirements are made up by one enterprise.

The innovators' and early adopters' were more specialized than the laggards' ratios, viz. 54 versus 43 . The index of specialization was significant at the one per cent level. RogERs points out that the first farmers to adopt a new practice do so, not only because they become aware of the practice sooner than their neighbour but because they require fewer years to move from awareness to adoption. Innovators perhaps gain part of their advantageous position (relative to other adopters) by learning about new practices at an earlier date, but the findings suggested that the most important reason why the innovators are the first in the process of adoption is because they require a shorter adoption period.

Rogers continues. Why do innovators require a shorter adoption period? Several reasons may be suggested. Innovators are more mresearchminded" and possess a stronger "science-orientation". Thus, an innovator has a more favourable attitude toward new technology and less "behavioural inertian must be overcome by communication stimuli. Innovators may have shorter adoption periods because they use more technically competent sources of information and because they place greater creditability in these sources than does the average farmer. Innovators may also possess a type of mental ability that enables them to deal with abstractions. An innovator must be able to conceptualize relatively abstract information from mass media sources and apply this new information on his own farm. Later adopters can observe the results of new farm practices on other farms and may not require this ability to deal with abstractions. BEAL and Rogers (2) found that

1) One PMWU or a productive man work unit is the amount of work performed in a ten-hour day by an average worker with typical methods and equipment. 
innovators scored significantly higher on a five-point rating on ability to deal with abstractions than did other adopter categories.

The innovator's part as a developer of technology is complementary to the more complicated efforts of the government and the commercial scientists. The farmer innovator further refines, modifies and perfects new farm ideas after their original development by others.

Hess and Miller (4) have carried out an interesting study in Pennsylvania, USA, one of the very few studies which deal directly with the subject under discussion. They point out that given comparable resources, productivity depends largely on the degree to which the operator makes correct decisions and implements them. This suggests that the determination of the factors which condition or influence farmers' decisions and actions is an underlying problem.

The objective of the study was to determine the factors or conditions responsible for the deviation of the existing level of performance on farms from some "feasible" standard of performace.

One of the major hypotheses was the influence of the operator's present state of knowledge on his actions and decisions. The level of knowledge of the farmers at least with regard to dairy farming, appeared to be largely related to the degree of success not only of the dairy enterprise but also of the total farm business. Operators with higher knowledge scores were also operating farms with a substantially larger total capital investment.

The apparent influence of knowledge on the returns was most evident at the higher levels of capital investment. For example, for an average capital investment of $\$ 14.000$ there was an associated increase in the labour income of $\$ 9,12$ for each point increase in the knowledge score. In contrast, the associated responses in labour income per unit increase in the knowledge score for average investments of $\$ 21.000$ and $\$ 35.000$ were $\$ 18.17$ and $\$ 36.27$ respectively. Therefore improved knowledge was associated with a four times greater response in labour incomes at the higher investment level than at the lower investment level. However, since improved knowledge is related to a number of other desirable characteristics in the operators, it would be unfair to attribute all of the associated responses in labour income at higher investment levels to improved knowledge alone.

The analysis disclosed a large degree of relationship between the level of formal schooling and the scores made on the knowledge test.

The mere possession of knowledge in itself is no assurance of financial success. This poses the question as to what other characteristics or traits are associated with the operators who have acquired their farming "know-how».

Since knowledge provides the basis for correct decisions and actions, what is the relationship between the level of knowledge and the actions of farmers. Operators with higher scores on the knowledge test possessed many other personal characteristics usually considered desirable; they were more progressive, and had a better idea of what is considered a good rate of milk production, they also culled their herds at a higher level. As a rule they adopted more of the recom- 
mended dairy practices than did the operators with the lower scores. These were the findings of Hess and Miller.

In the year 1954 an investigation was started in Finland under the supervision of Westermarck (8) with the aim of elucidating the influence of intensified individual advisory work on management, including the re-allocation and re-organization of resources and their success on 41 family farms. The investigation covered a period of five years. The farms in question consisted of two groups, one in south Finland ( 32 farms with an average of 12.6 hectares arable land) and one in central Finland (9 farms with an average of 12.4 hectares arable land).

The central problem on these farms was to bring the various branches of the farming business into a proper inter-relationship so that eventually they would form a unit producing better economic results (unit thinking).

Great differences were noticed in the views of the farmers toward planning and the realization of the plans. Especially when the alterations were considerable it was usually harder for farmers who had operated their farms for longer periods to make decisions on the alteration than it was for farmers who had obtained the farm recently or who had operated it only for a few years. However, the farmers of the latter group were generally younger than those in the former group. Consequently, the more positive attitude of younger persons towards alterations characterized the prevailing differences in attitudes. Usually the farmer who had managed his farm for a longer period had to have a stronger belief in the profitableness of alterations than in the instances where farming had not yet settled in to grooves.

Some facts should be mentioned regarding the distribution of the gross return among different branches of production. Concurrently with the proportion of cash crops having decreased in central Finland with its relatively unfavourable climate, a slight growth was perceptible in the ratios of all branches of livestock husbandry. On the other hand, on the study farms of southern Finland with their better climate conditions, the tendency was the opposite, and the share of milch cattle husbandry had decreased. Although no revolutionary changes occurred in the ratios between crop husbandry and livestock husbandry, it might be claimed that the development was towards regional specialization.

No decrease in the labour input was observed on the study farms of central Finland; on the contrary, the trend was to increase labour. This is probably not a change result, since on the farms in central Finland, which had been very extensively cultivated earlier, the attainment of full employment has been pursued by such means as intensifying cultivation, increasing livestock husbandry and including new types of livestock production in the business. In these cases the farms had abundant labour available.

On the other hand, in southern Finland, where there was a shortage of labour, the farms tried to cut down the need of labour by increasing the use of tractors, by efficient organization and by work simplification. On these farms, the number of enterprises was cut down, especially the ones serving home consumption.

These observations thus lead to the conclusion $\mathrm{th}$ a $\mathrm{t}$ in circumstances where labour power is abundant, and the area of the farm cannot be increased, the specialization and simpli- 
fication of production are not so evident as on farms where lack of labour power prevails.

Recently, the Indian Purohit (6) carried out a research in Finland on the connections between the adoption of innovations, measured by a certain adoption scale, and such factors as the ability of the farmer and the farming couple, the age of the farmer and his professional training.

The improved farm practices included in the schedule were the following 1) soil test, 2) seeded pasture, 3) use of insecticides, 4) making of silage fodder, 5) the use of artificial insemination, 6) running water in the cow shed and 7) the use of milking machine.

The adoption score scheme was based on 1) the number of specified farm practices adopted by the farmer and 2) the time required by the actual adoption since the farmer had taken over the farm as an undertaking of his own.

The following chapters disclose the fact that there exists a positive correlation between the ability of the farming couple and the adoption of innovations. $\mathrm{T} h \mathrm{e}$ more able farmers had rapidly adopted new methods to a pronouncedly greater extent than the less able far$\mathrm{m}$ e rs. It was observed on this research that the wife of the farmer was of great significance regarding the adoption of new methods.

$\begin{array}{cc}\begin{array}{c}\text { The ability of the farming } \\ \text { couple in points }\end{array} & \begin{array}{c}\text { Adoption of new methods } \\ \text { in points }\end{array} \\ \text { more than } 74 & 31 \\ 65-74 & 26 \\ \text { less than } 65 & 20\end{array}$

It was also apparent that farmers who had received theoretical training adopted new methods faster than farmers without theoretical training. It should be mentioned that for the farmers who had gone through a vocational school, the points for adopting new methods were 33 , and for farmers without vocational training the points remained at 24 . The former group included 67 , and the latter 113 farmers. Statistically the difference was significant.

When the farmers were divided into four age groups - under 40 years, $40-49$ years, 50-59 years and older farmers - it was evident that the younger farmers seemed to have adopted innovations faster than older farmers. However, the differences were not statistically significant. On the contrary, it was quite obvious that if the farmers were divided into two groups according to how long they had been running their farms, those farmers who had managed their farm for less than 15 years were more inclined to adopt new methods than those who had managed their farm for more than 15 years. This difference was statistically indicative.

In dealing with the question of the farmer's influence on the organization and technical level of crop husbandry versus livestock husbandry, the assumption can be made that his handling of, or in other words, his personal significance in the organization of livestock production is on a firmer basis than in plant cultivation, 
since the weather factor in particular has a far greater influence on crop husbandry and the soil quality is often a factor on which ability has only a limited effect. The research of PURoHit conducted in Finland revealed that the effect of the ability level on the level of the yield in crop husbandry was not as significant as it was on milk production per cow. It is interesting to note that the ability of the farmer's wife appeared in addition to have an essential and positive effect on the production level of milch cattle enterprise.

\section{Conclusions}

This essay has sought to elucidate the issue of the influence of the human factor on the re-organization of production. However, very little empirical material dealing with the substance of the matter seems to exist, for which reason the issue has been dealt with somewhat peripherally.

Certain conclusions may, nevertheless, be drawn.

The significance of managerial skill in the reorganization of production and re-allocation of resources will continuously increase in importance in the future for the following reasons, which are all inter-related:

Science and techniques are with increasing speed achieving technical improvements in methods, the sufficiently rapid adoption of which requires increasing alertness to enable the farmer to keep up with the times.

It is not possible to create a rationally managed farm unit without resorting to new technical achievements, so the farmers of these farms are allowed to attain an income level deemed moderate by the government in its official agricultural policy.

The size of the farms, expressed according to area, or man work units or in some other way, tends to increase, which also involves a closer dependence on credit granting.

Farms are becoming increasingly commercial which requires a business training.

It is obvious that the advantage of ability is considerably greater in those undertakings in which more capital is invested, taking into consideration the continuing growth of the part played by capital in the business.

In order that the realization of the re-organization would keep pace with the technical development, sufficient attention should be given to

1) the attaining of up-to-date professional training

2) a sufficiently rapid succession of generations in the farming.

\section{REFERENCES}

(1) Ban, A. W. van den, 1961. Research in the field of advisory work. Neth. J. Agric. Sci. $9: 2$.

(2) Beal, George M. \& Rogers, Everett, M., 1958. The importance of personal influence in adoption of technological changes. Social Forces 4. Baltimore.

(3) DAw, M. E., 1962. Are our farming systems too complicated? Farm Management Notes, Univ. o Nottingham 28. Loughborough. 
(4) Hess, C. C. \& Miller, L. F., 1954. Some personal, economic and sociological factors influencing dairymen's actions and success. Pennsylvania State Univ. College of Agriculture Bulletin 577 .

(5) Partenhetmer, Earl J. \& Bell, Robert D., 1961. Managerial behaviour of farmers in formulating exceptations of future events. (A study of managerial processes of Midwestern farmers.), Iowa State, Ames, Iowa.

(6) Purohit, Bhagwan Das, 1963. The economic implications of human ability on Finnish bookkeeping farms. Acta Agr. Fenn., 101: 2, Hämeenlinna.

(7) Rogers, Everetr M., 1961. Characteristics of agricultural innovators and other adopter categories. Ohio Agr. Exp. Res. Bull. 882.

(8) Westermarck, N., 1960. Management and success in farming, Part III. Influence of individual advisory services, Acta Agric. Scand. X: 4 Stockholm.

S E L OS T U S :

HENKILÖKOHTAINEN PANOS MAATALOUSLIIKKEEN UUDELLEEN JÄRJESTELYSSÄ

\author{
N. Westermarck \\ Helsingin yliopiston maanviljelystalouden laitos
}

Kirjoituksessa esitetäăn katsaus ns. inhimillisten tekijöiden vaikutukseen maatalousliikkeen järjestelyssä ja mahdollisuuksien käytőssä. Päätelmänä todetaan, että maatalousyrittäjän henkilökohtaiset ominaisuudet ja hänen pystyvyytensä ovat nykyajan dynaamisessa maataloudessa tärkeämpiä tekijöitä kuin aikaisemmin ja niiden merkitys tulee edelleen kasvamaan seuraavista syistä.

Tutkimuksen ja uuden tuotantotekniikan merkitys lisäăntyy kiihtyvällä nopeudella, jolloin vaatimus, että niiden tuloksia myös sovelletaan käytäntöön kasvaa, mikäli maatalousyrittäjä haluaa välttyä jäämästä jälkeen muiden alojen yritysten kehityksestä progressiivisessa yhteiskunnassa.

Ei ole mahdollista aikaansaada rationaalisesti hoidettuja yrityksiä ilman lisääntyvää ammattitaitoa eikä edes teoreettisestikaan ole mahdollista saavuttaa ns. tulotasopariteettia, mikä monissa maissa on omaksuttu maatalouspolitiikan tavoitteeksi.

Yrityksen liiketaloudellinen koko tulee kasvamaan, mikä tietää suurempaa riippuvuutta pääomamarkkinoista.

Maatila muodostuu yhä selvemmin liikemiesmäisten periaatteiden mukaan harjoitettavaksi yritykseksi.

Tiedontason merkitys kannattavuustekijänä on sitä suurempi, mitä enemmän pääomaa yritykseen sijoitetaan ottaen huomioon, että tulevaisuudessa pääomapanos maatalousyrityksissä tulee jatkuvasti nousemaan työvoimapanoksen supistuessa. 